\title{
ALERGIJA KARVĖS PIENUI
}

\author{
Doc. dr. Jolanta Kudzyte
}

KMU Vaikų ligų klinika

\begin{abstract}
REIKŠMINIAI ŽODŽIAI: alergija karvès pienui, alergija maistui, vaikai.
SANTRAUKA. Alergija karvės pienui - padidèjęs organizmo jautrumas karvės pieno baltymams, sukeliantis imuninį atsaką. Daugeliu atveju ji esti polivalentinès alergijos maistui dalis, taigi nustatomas įsijautrinimas ir kitiems maisto produktams. Karvės pienas - dažniausiai vartojamas produktas pirmaisiais gyvenimo metais, todèl alergija karvės pienui iš visų alergijos maistui atvejų pirmaisiais gyvenimo metais pasitaiko dažniausiai. Karvės piene yra daugiau nei 30 j̨vairių baltymų, 0 dažniausiai alergines reakcijas sukelia išrūgų baltymas $\beta$ laktoglobulinas. Alergija karvės pienui gali paveikti daugeli organy̨ ar sistemų bei sukelti sistemines reakcijas. Pagal klinikinių simptomų pasireiškimo laiką visos reakcijos skirstomos i greitas, lètas ir uždelstas. Veiksmingiausia būtų pašalinti karvès pieną ir jo produktus iš vaiko mitybos, o vietoj jo duoti sojų pieno, hidrolizuotų baltymų ar aminorūgščių mišinių. Norint silpninti baltymų alerginį poveikį, reikia sumažinti baltymų molekules iki peptidų ar net aminorūgščių. Tai galima padaryti hidrolizės būdu. Iš dalies hidrolizuotais mišiniais profilaktiškai maitinami kūdikiai esant atopinei anamnezei, kol dar nèra alergijos klinikinių simptomų. Labai hidrolizuoti ir aminorūgščių mišiniai skirti vaikams gydyti, kai jau yra klinikinių alergijos karvès pienui ar jo netoleravimo simptomų.
\end{abstract}

\section{IVADAS}

Hipokratas (460-370 m. prieš Kr.) pirmasis aprašè alergiją karvès pienui - odos ir virškinimo sistemos sutrikimo simptomus. Vèliau Galenas (131-210 m. po Kr.) apibūdino alergines reakcijas, kurios pasireiškè vaikui, išgėrusiam ožkos pieno. V. Schosman ir M. Finkelstein 1905 m. aprašè anafilaksijos atvejus išgèrus karvès pieno, o D. Hutinel 1908 m. greito tipo reakcijas vaikams, gèrusiems pieno mišinius.

Nepageidaujamą reakciją i karvès pieną gali lemti imuninès, metabolinès, infekcinès ar kitos priežastys. Alergija karvès pienui - padidejjęs organizmo jautrumas karvès pieno baltymams, sukeliantis imuninị atsaką. Imuninis atsakas gali būti susijęs su antikūnais (IgE ar IgG) arba ląstelèmis (limfocitais). Neimuninių mechanizmų lemiama nepageidaujama reakcija, kai stinga laktazès, vadinama karvès pieno (laktozès) netoleravimu.

Karvès pienas - dažniausiai vartojamas produktas pirmaisiais gyvenimo metais, todèl alergija karvès pienui iš visų alergijos maistui atvejų pirmaisiais gyvenimo metais pasitaiko dažniausiai. Nors teigiama, kad alergiški karvès pienui 5-15 proc. kūdikių, tik trečdaliui šių vaikų tai patvirtinama provokaciniais mėginiais. Iš neatopiškuc kūdikių alergija karvès pienui diagnozuojama 2-3 proc., o iš atopiškų - net 10 proc. Net 50 proc. kūdikių, sergančių atopiniu dermatitu, yra alergiški karvės pienui. Daugelis vaikų „išauga“ alergiją karvès pienui iki 5 metų. Alergijos karvės pienui rizikos veiksniai yra atopinė šeimos anamnezė ir anksti pradètas maitinimas karvès pienu.

\section{PATOFIZIOLOGIJA}

Ijautrinti organizmą gali bet kuris maisto produktu baltymas, jei jis nepakitęs ar jo fragmentas absorbuojamas per žarnyno gleivinę, - tai sukelia imuninị (alerginị) atsaką. Karvès piene yra daugiau nei 30 ivvairių baltymų, kurių 80 proc. sudaro kazeinas, o 20 proc. - išrūgos. Dažniausiai alergines reakcijas sukelia išrūgų baltymai: $\beta$ laktoglobulinas, jaučio serumo albuminas, $\gamma$ globulinas, $\alpha$ laktalbuminas, laktoferinas. Kartais dèl sutrikusios sekrecinio IgA funkcijos pakinta virškinimo sistemos gleivinès imunitetas, dèl to dar labiau padidejja nepakitusio baltymo absorbcija. İ organizmą patekęs baltymas skatina antikūnų ar ląstelių sukeliamą imuninị atsaką, kliniškai pasireiškianti alergijos karvès pienui simptomais. Pasterizavimas, džiovinimas, miltelių gamyba, tirštinimas, garinimas tik sumažina, bet nepanaikina pieno baltymų alerginio poveikio $[1,3,4,6]$. 


\section{KLINIKINIAI SIMPTOMAI}

Alergija karvès pienui gali paveikti daugeli organų ar sistemų (odą, kvejpavimo, virškinimo ar net sukelti sistemines reakcijas) (1 pav.). Simptomų pasireiškimo dažnumas pateikiamas 1 lentelëje [2]. Alergija karvès pienui daugeliu atveju yra polivalentinès alergijos maistui dalis, todèl nustatomas ịsijautrinimas ir kitiems maisto produktams (2 pav.).

Pagal klinikinių simptomų pasireiškimo laiką visos reakcijos skiriamos i greitas, lètas ir uždelstas (2 lentelè). Jei išgèrus nedideli kiekị karvès pieno, simptomai išryškẻja po 0,5-1 val., - tai greitos reakcijos. Jos yra sukeliamos IgE, geriausiai diagnozuojamos atliekant odos dūrio méginius (ODM) ar tiriant specifinius IgE. Kadangi galimos klaidingai teigiamos reakcijos, labai svarbu jas atlikti iki vieneriu metụ amžiaus, kai tokių reakcijụ tikimybė mažesné. Tačiau „auksinis standartas“ - placebu kontroliuojamas dvigubai aklas maisto méginys (PKDAMM). Ivykus greitai reakcijai klinikiniai simptomai būna labai ịvairūs.

Jei išgèrus vidutini kieki karvès pieno simptomai išryškejja po keliụ valandụ, - tai lètos reakcijos. Šių reakcijų atveju dažniausiai pasireiškia virškinimo sistemos sutrikimo simptomai. Diagnozuojama atliekant atvirą provokacini mèginį (MPM) bei PKDAMM.

Uždelstos reakcijos yra mažiausiai ištirtos, manoma, kad jas sukelia ląstelès. Simptomų atsiranda išgérus didelị kiekị pieno, po kelių dienų, dažniausi odos (egzema) ir virškinimo sistemos (viduriavimas) simptomai. Diagnozuojama atliekant odos lopo mégini (OLM) ir PKDAMM $[2,3,4,6]$.
1 lentelè. KLINIKINIAI ALERGIJOS KARVĖS PIENUI POŽYMIAI (PROF. DUBAKIENĖ. ALERGINIŲ LIGŲ VADOVAS. 2003)

\begin{tabular}{|c|c|}
\hline Simptomas & $\begin{array}{c}\text { Dažnumas } \\
\text { (proc.) }\end{array}$ \\
\hline \multicolumn{2}{|c|}{ Virškinimo organai } \\
\hline Vèmimas & 39 \\
\hline Viduriavimas & 48 \\
\hline Pilvo diegliai & 14 \\
\hline Kolitas & 4 \\
\hline Funkcinè žarnų obstrukcija & 3 \\
\hline Svorio augimo sutrikimai & 22 \\
\hline Gastroezofaginis refliuksas & 6 \\
\hline \multicolumn{2}{|c|}{ Oda } \\
\hline Generalizuota dilgèlinè & 10 \\
\hline Angioedema & 13 \\
\hline I tymus panašus išbėrimas & 6 \\
\hline Atopinis dermatitas (egzema) & 39 \\
\hline Tarpvietès išbèrimas & 1 \\
\hline \multicolumn{2}{|c|}{ Kvèpavimo organai } \\
\hline Pasikartojantis stridoras & 4 \\
\hline Sloga & 21 \\
\hline Kosulys, švokštimas & 29 \\
\hline Tachipnèja & 1 \\
\hline \multicolumn{2}{|c|}{ Nervụ sistema } \\
\hline Irzlumas, dirglumas & 40 \\
\hline Kolapsas & 12 \\
\hline Traukuliai & 2 \\
\hline \multicolumn{2}{|c|}{ Kiti požymiai } \\
\hline Generalizuota anafilaksija & $3-5$ \\
\hline Mažakraujystè & 2 \\
\hline Osteoporozè & 1 \\
\hline
\end{tabular}

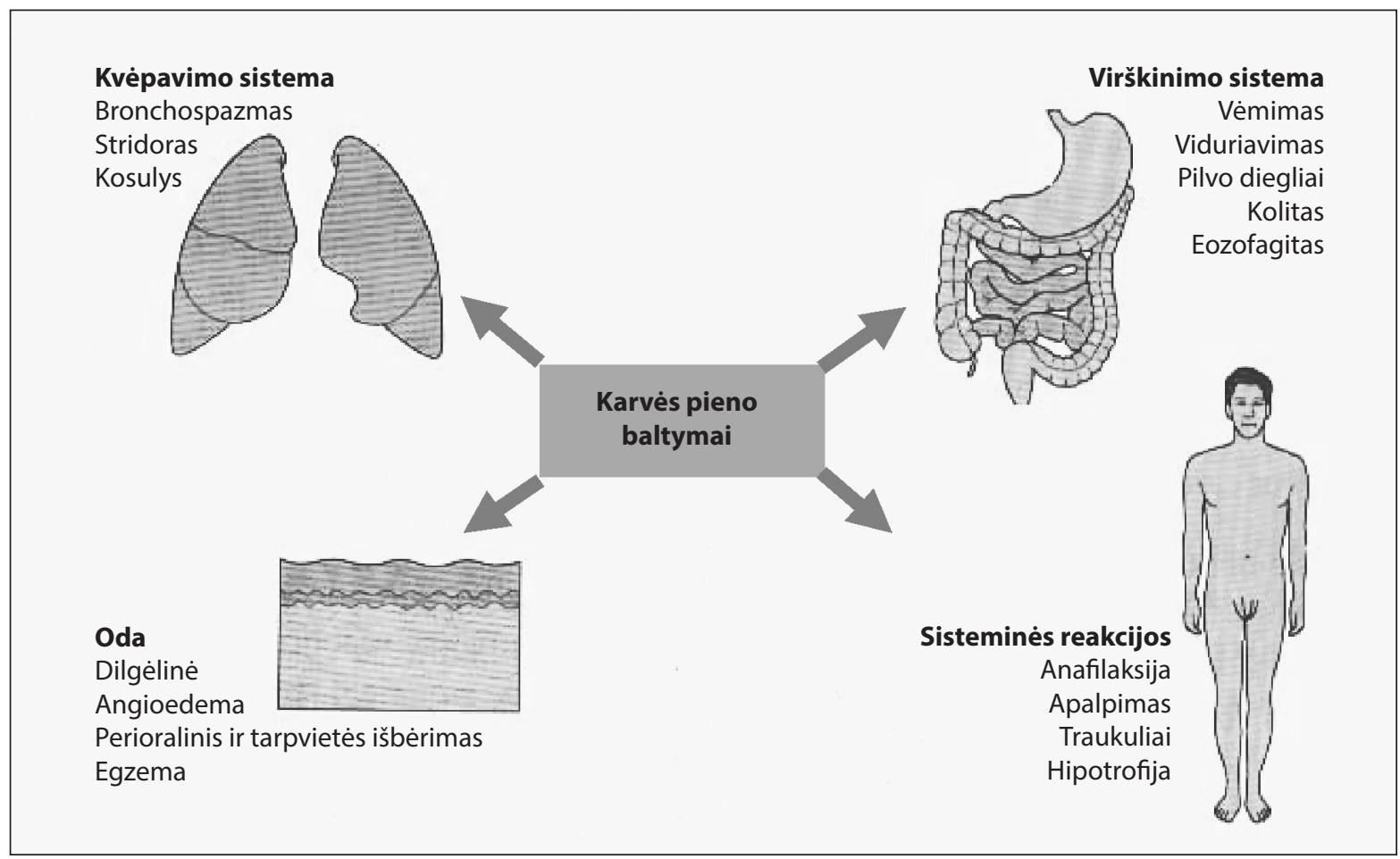

1 pav. DAŽNIAUSI ALERGIJOS KARVĖS PIENO PASIREIŠKIMO POŽYMIAI 


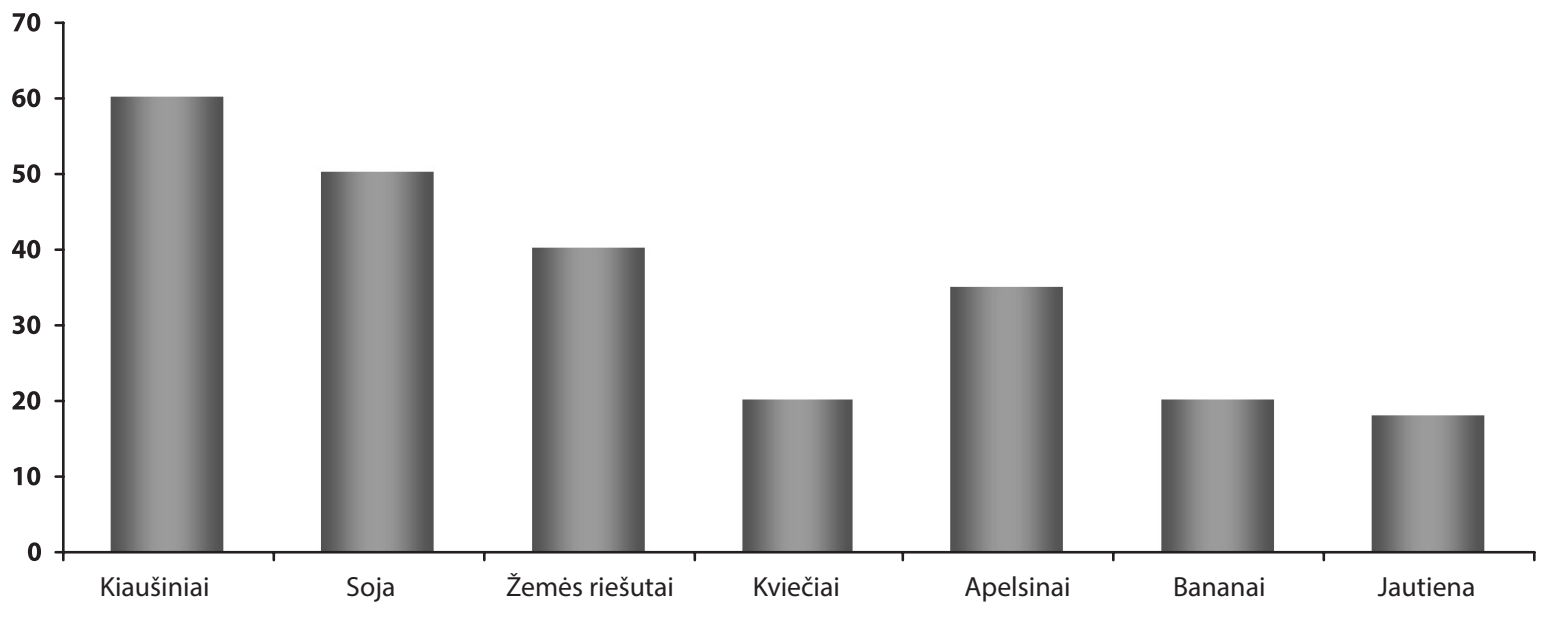

2 pav. VAIKŲ, ALERGIŠKŲ KARVĖS PIENUI, ISIJAUTRINIMAS KITIEMS MAISTO ALERGENAMS (S. H. ARSHAD ALLERGY, 2002)

\section{DIAGNOSTIKA}

Alergija karvès pienui dažniausiai diagnozuojama remiantis anamneze ir klinikiniais simptomais. Žinoma, auksinis standartas diagnozuojant šią alergiją tebèra placebu kontroliuojamas dvigubai aklas maisto méginys. Jei pagal anamnezę ir kliniką diagnozė yra beveik aiški, galima atlikti ir atvirą maisto provokacini mégini (3 pav.). Jo negalima daryti, jei būta sisteminiu reakcijų ar anafilaksinio šoko. Odos dūrio mèginiai ar specifiniu IgE tyrimas padeda atskirti greitas IgE sukeliamas reakcijas nuo kitų reakcijų. Odos lopo mèginiai rodo uždelstas reakcijas. Diagnozuojant alergiją karvès pienui rekomenduojama atlikti odos dūrio ir lopo méginius greitoms ir uždelstoms reakcijoms nustatyti. Būtina įvertinti vaiko fizinę raidą (ūgị ir svorị). Gali būti atliekami išmatų, endoskopiniai, prakaito ir kiti tyrimai norint atmesti kitas virškinimo trakto sutrikimo priežastis [1].

\section{GYDYMAS}

Veiksmingiausia būtų pašalinti karvès pieną ir jo produktus iš vaiko mitybos. Tai padeda atkurti žarnų apsauginị barjerą. Sumažejjus žarnyno pralaidu-

2 lentelè. ALERGIJOS KARVÉS PIENUI KLINIKINIAI SIMPTOMAI IR REAKCIJŲ TIPAI (D. J. HILL IR KT., P. BAEHLER IR KT., 1996)

Reakcijos laikas / išgerto karvès pieno kiekis

\begin{tabular}{|c|c|c|c|}
\hline & $\begin{array}{l}\text { Greitos reak- } \\
\text { cijos / mažas } \\
\text { kiekis }\end{array}$ & $\begin{array}{l}\text { Lètos reakcijos } \\
\text { / vidutinis } \\
\text { kiekis. }\end{array}$ & $\begin{array}{l}\text { Uždelstos } \\
\text { reakcijos / } \\
\text { didelis kiekis }\end{array}$ \\
\hline Oda & $\begin{array}{l}\text { Dilgèlinè, } i \\
\text { tymus panašus } \\
\text { išbèrimas }\end{array}$ & & Egzema \\
\hline $\begin{array}{l}\text { Virškinimo } \\
\text { traktas }\end{array}$ & Vèmimas & $\begin{array}{l}\text { Vèmimas ir / ar } \\
\text { viduriavimas }\end{array}$ & Viduriavimas \\
\hline $\begin{array}{l}\text { Kvèpavimo } \\
\text { takai }\end{array}$ & $\begin{array}{l}\text { Švokštimas, } \\
\text { rinorèja }\end{array}$ & & \\
\hline $\begin{array}{l}\text { Diagnozavi- } \\
\text { mas }\end{array}$ & $\begin{array}{l}\text { ODM, spec. } \\
\text { IgE, MPM ar } \\
\text { PKDAMM }\end{array}$ & $\begin{array}{l}\text { MPM ar } \\
\text { PKDAMM }\end{array}$ & $\begin{array}{l}\text { Lopo mėginys, } \\
\text { MPM, PKDAMM }\end{array}$ \\
\hline
\end{tabular}

mui, sumažèja ir kitu maisto alergenụ absorbcija. Po eliminacinès dietos sumažèja klinikinių simptomų, specifinių IgG ir IgE karvės pienui kiekis. Vietoj karvès pieno galima vartoti sojų pieną, hidrolizuotų baltymų ar aminorūgščių mišinius. Renkantis

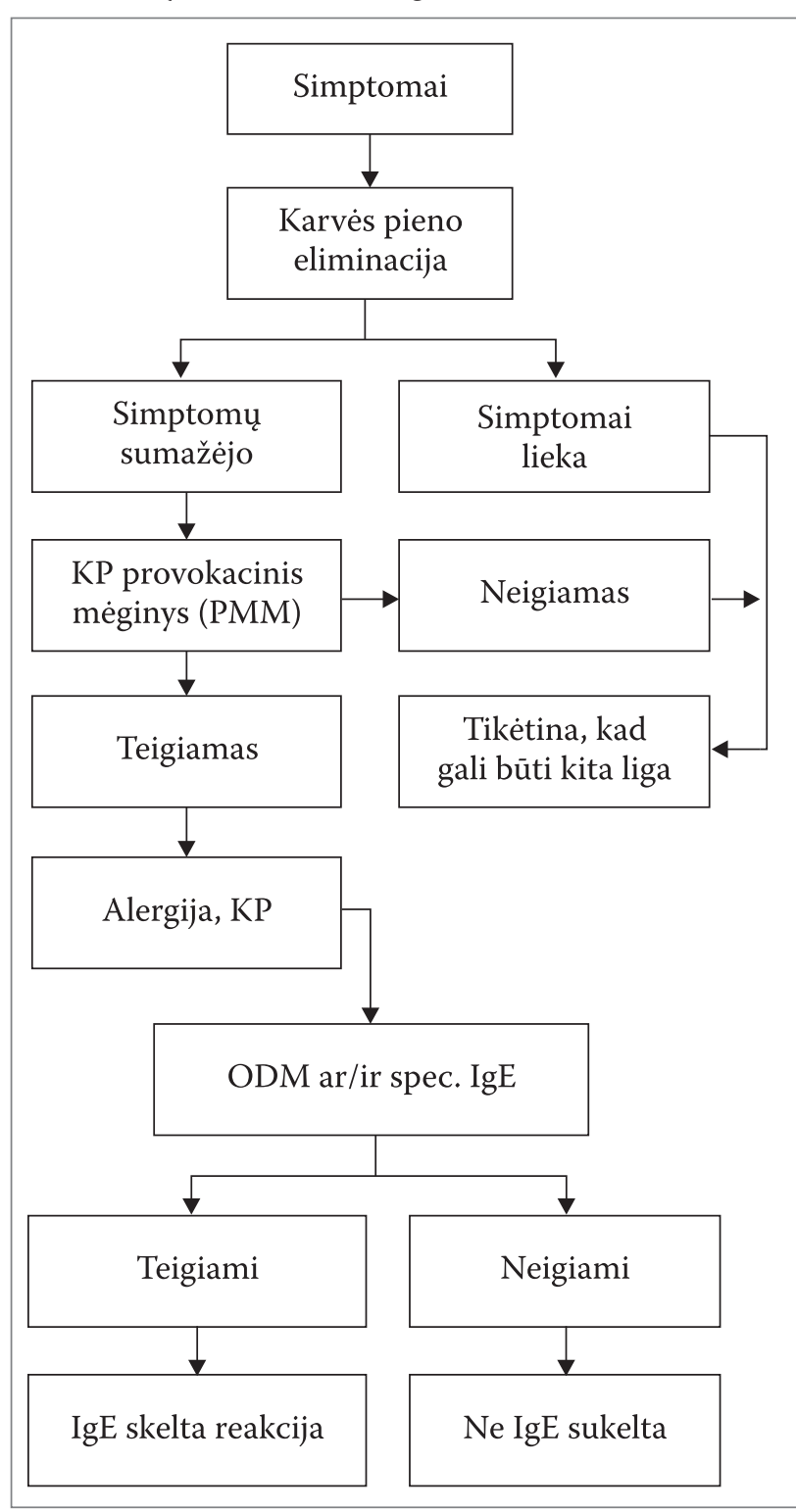

3 pav. ALERGIJOS KARVĖS PIENUI DIAGNOSTIKOS ALGORITMAS 
3 lentelè. LIETUVOJE REGISTRUOTU HIDROLIZUOTY̨ MIŠINIŲ KŪDIKIAMS ALERGIŠKUMAS

\begin{tabular}{|c|c|}
\hline Iš dalies hidrolizuoti mišiniai & $\beta$ laktoglobulino kiekis $\mu \mathrm{g} / \mathrm{g}$ \\
\hline $\begin{array}{ll}\cdot & \text { Aptamil HA } \\
\cdot & \text { NAN, HA } \\
\cdot & \text { HiPP HA } \\
\cdot & \text { Humana HA } \\
\cdot & \text { Similac Advance HA } \\
\end{array}$ & $83-85$ \\
\hline \multicolumn{2}{|l|}{ Labai hidrolizuoti mišiniai } \\
\hline $\begin{array}{ll} & \text { Alfa-Re } \\
\text { - } & \text { Aptamil Pepti } \\
\text { - } & \text { Aptamil Pepti MCT } \\
\text { - } & \text { Tutteli-Peptidi } \\
\end{array}$ & $\begin{array}{c}0,12 \\
0,0061 \\
0,0061 \\
0,011 \\
\end{array}$ \\
\hline \multicolumn{2}{|l|}{ Aminorūgščių mišiniai } \\
\hline $\begin{array}{ll}\text { - } & \text { Nutrijunior } \\
\text { - } & \text { Neocate }\end{array}$ & $\begin{array}{c}0,031 \\
0,0016\end{array}$ \\
\hline $\begin{array}{l}\text { Labai hidrolizuoto mišinio antig } \\
\text { milijonais mažesnis už nehidrol } \\
\text { motinos pieno. }\end{array}$ & $\begin{array}{l}\text { inio baltymo kiekis yra keliais } \\
\text { Ioto mišinio ir toks pat kaip }\end{array}$ \\
\hline
\end{tabular}

mišinius reikia atsižvelgti ị vaiko ịsijautrinimo stiprumą, mitybos poreikius, mišinių kainą.

Alergija sojos pienui visame pasaulyje plinta ir jau siekia 75 proc., todèl sojos mišiniais kūdikių rekomenduojama nemaitinti [1].

\section{HIPOALERGINIAI MIŠINIAI}

Alergines reakcijas gali sukelti didelès baltymų molekulès (antigenai), skatinančios antikūnų gamybą. Norint susilpninti baltymu alergini poveikị, reikia sumažinti jų molekules iki peptidu ar net aminorūgščių. Tai galima padaryti hidrolizès būdu, o taip gaminami pieno mišiniai vadinami hidrolizuotais. Labai hidrolizuotuose pieno mišiniuose 95 proc. peptidu molekulinis svoris nesiekia 1500 daltonų, ir tik mažiau kaip 0,5 proc. peptidų esti apie 6000 daltonų. Iš dalies hidrolizuotuose pieno mišiniuose 6000 daltonų būna net $2-18$ proc. peptidụ. Didesni peptidai gali sukelti alergines reakcijas, nes turi polinkị prisitvirtinti prie žmogaus serumo IgE. Odos ar maisto provokaciniai méginiai bus teigiami. Iš dalies hidrolizuotụ mišiniụ skiriama rizikos grupès kūdikiams (atopinè kūdikio anamnezè), kol dar nèra alergijos klinikiniu simptomų. Jais jokiu būdu negalima gydyti alergijos karvès pienui, nes gali kilti alerginių reakcijų ir net anafilaksinis šokas. Labai hidrolizuoti ir aminorūgščių mišiniai skirti vaikams gydyti, kai jau yra klinikinių alergijos karvès pienui ar jo netoleravimo simptomų. Iš aminorūgščiu pagamintuose mišiniuose peptidu nèra, todèl jie visiškai saugūs alergijos karvès pienui atvejais (3 lentelè) [3, 7].

Kartais hidrolizuoti mišiniai neatitinka vaiko mitybos poreikių, nes mažinant alergiškumą pakinta aminorūgščiu sudètis arba sumažèja biopraeinamumas. Buvo pastebèta $\mathrm{Ca}, \mathrm{Zn}, \mathrm{Cu}$ absorbcijos sutrikimų. Prieš skiriant labai hidrolizuotą mišinị, reikia atlikti odos dūrio mèginius. Jeigu jie neigia- mi, mišini skirti galima. Jeigu odos mėginiai teigiami, reikia atlikti atvirus maisto provokacinius méginius stacionare, kur yra skubiosios pagalbos priemoniu ir sąlygos gaivinti. Jei reakcija teigiama, skiriama aminorūgščių mišinių, be to, jų skiriama ir tada, kai kūdikiui valgant labai hidrolizuotus pieno mišinius nustoja augti svoris.

\section{PROFILAKTIKA}

Kūdikius, priskiriamus rizikos grupei (teigiama atopinè anamnezè), reikia maitinti tik motinos pienu 6 mènesius, o iki 12 mènesiu motinos pienu ir papildomais produktais. Kadangi nepakitęs karvès pieno baltymas patenka ị motinos pieną iš mamos raciono, žindanti motina turi riboti karvès pieno produktus ar visiškai jų nevalgyti. Jei mama nežindo, kūdikis maitinamas hidrolizuotais mišiniais. Viena blogybė, kad jie kartūs ir neskanūs. Jei valgant labai hidrolizuotus mišinius, nustotụ augti svoris ir ūgis, reikètų skirti aminorūgščiu mišinị. Kas 6-12 mèn. reikia išmėginti netoleruojamą produktą, nes daugelis vaikų pradeda kliniškai toleruoti maisto produktus jau per pirmuosius trejus gyvenimo metus $[1,3,4]$.

\section{COW MILK ALLERGY \\ Jolanta Kudzyte \\ Clinic of Child Diseases \\ Kaunas University of Medicine}

Key words: cow milk allergy (CMA), food allergy, children.

Summary. Cow milk allergy is defined as hypersensitivity to cow milk proteins whose pathogenesis involves an immune response to cow milk proteins. Responses are classified as immediate, intermediate or delayd clinical reactions according of time between ingestion of cow milk and the apperance of clinical symptoms which affect the skin, gastrointestinal and respiratory tracts. The use of substitute formula seems to be essential up to the age of least two years to ensure normal growth. Exensively hydrolysed formulae is based on hydrolysed proteins with fragments small enough not to induce allergic reactions in sensitised children. If children who do not tolerate extensively hydrolysed formulae or growth retardation (failure to thrive) is a problem, intervention with amino acid based formula may be recommended.

\section{LITERATŪRA}

1. S. H. Arshad. Allergy // Churchill Livingstone, London 2002

2. Alerginių ligų vadovas // Sudarytoja prof. R. Dubakienè, Vilnius 2003.

3. D Hill. E. Isolauri. Guide for Pediatricians on the Diagnosis and Treatment of Severe Cow Milk Allergy and Multiple Food Protein Intolerance in Infancy //1998.

4. R. L. Wolf. Essential Pediatric Allergy, Asthma and Immunology // Mc. Grow - Hill Companies, USA 2004.

5. M. T. Krishna, S.T. Holgate. Essential of Allergy // Martin Dunitz Ltd, London 2001.

6. Managing allergens in food edited by Clare Mills // CRC Cambridge 2007.

7. E. Isolauri et all. Efficacy and safety of hydrolysed cow milk and amino acid-derived formulas in infants with cow milk allergy // J.Pediatr 1995

8. P. Baehler et all. Distinct patterns of cow's milk allergy in infancy defined by prolonged two stage double-blind, placebo-controlled food challenges // Clin.Exp.Allergy 26, 1996. 